\title{
Familial Occurrence of a Small, Supernumerary Metacentric Chromosome in Phenotypically Normal Women
}

\author{
M. A. C. RIDLER, J. M. BERG, ^ MADELEINE J. PENDREY, P. SALDANA, and \\ J. A. D. TIMOTHY
}

From the Kennedy-Galton Centre, Harperbury Hospital, St. Albans, Hertfordshire

Atypical, additional, metacentric chromosomes, approximating in size to that of $\mathrm{G}$ group chromosomes, have been reported in patients with undifferentiated types of mental retardation and congenital malformation (Frøland, Holst, and Terslev, 1963; Gustavson, Atkins, and Patricks, 1964; Taft, Dodge, and Atkins, 1965; Tamburro and Johnson, 1966; Ferrante et al., 1968; Ishmael and Laurence, 1968; Mukherjee et al., 1968), with Down's syndrome (Dekaban, 1965; Townes, 1968), with psychosis (Anders et al., 1968), and with oligospermia (Smith et al., 1965). The presence of additional 'minute' metacentrics has been noted in cases recorded by Hultén et al. (1966), by Fischer and Haslund (1968), and by Ginsberg, Dignan, and Soukup (1968). Occasionally, an extra metacentric has also been found in normal, healthy individuals (Smith et al., 1965; Townes, 1968).

The derivation and possible significance of these supernumerary fragments is obscure, and substantial phenotypic variation has been associated with their presence in the human karyotype. This report presents data on a family in which each of three phenotypically normal women has an additional small metacentric chromosome, and provides evidence as to the possible identity of the extra fragment.

\section{Family Data}

In the course of investigating the case of a child with delayed motor development and mental retardation, chromosomal analysis revealed an apparently normal karyotype, but his mother's (J.Y.) karyotype showed the presence of an extra small metacentric chromosome. Further study of the family showed that the karyotypes of J.Y.'s mother and twin sister also contained a similar additional chromosome.

Received 5 November 1969.

* In receipt of a grant from the Medical Research Council.
A pedigree of the family is shown in Fig. 1. II.5 has a normal daughter (III.2), in addition to the clinically affected son (III.3), and a third pregnancy terminated in a miscarriage (III.4) at 4 months. She has a probably monozygotic twin sister (II.4), an older sister (II.3), and an older brother (II.1) whose wife had one 'miscarriage

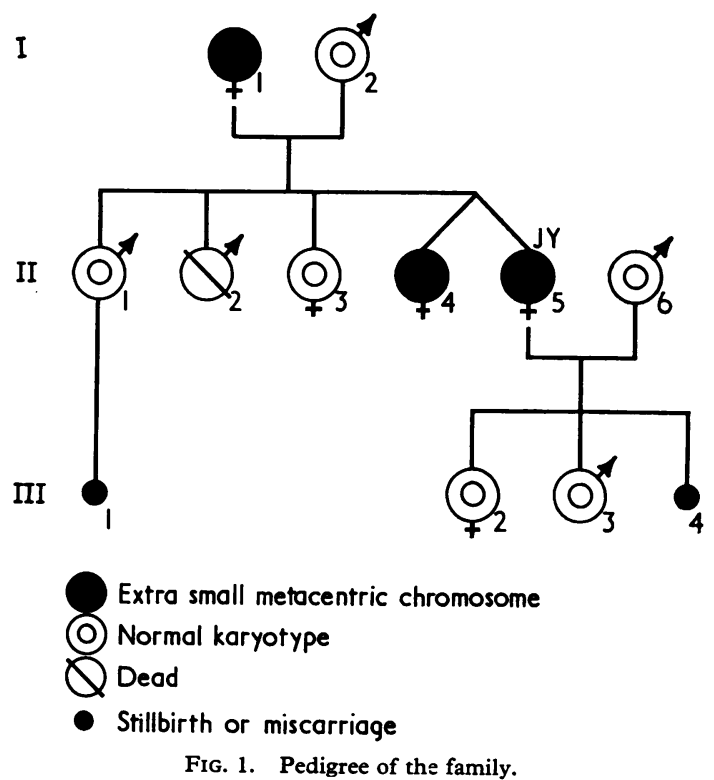

or ectopic pregnancy' (III.1). Another brother (II.2) of II. 5 was born prematurely at 7 months and died after 2 hours. Apart from the retarded child (III.3), no relatives are known to be phenotypically abnormal, and there is no family history of consanguinity.

\section{Cytological Investigations}

Peripheral blood for leucocyte culture, and skin biopsies for fibroblast culture, were taken from II.5, her twin sister (II.4) and her son (III.3). Leucocyte 
TABLE I

CHROMOSOMAL FINDINGS IN FAMILY

\begin{tabular}{|c|c|c|c|c|c|c|c|}
\hline $\begin{array}{l}\text { Pedigree } \\
\text { No. }\end{array}$ & Sex & $\begin{array}{l}\text { Age } \\
\text { (yr.) }\end{array}$ & Tissue† & $\begin{array}{l}\text { No. of } \\
\text { Cells }\end{array}$ & Karyotype & \multicolumn{2}{|c|}{ Comment } \\
\hline I.1 & $\mathbf{F}$ & 61 & $\mathbf{L}$ & 150 & $\left(\begin{array}{lr}\left(46 / X_{0}\right. & 8 \%\end{array}\right)$ & $\begin{array}{l}\text { Extra small metacen- } \\
\text { tric in all cells }\end{array}$ & $\begin{array}{l}\text { Large acentric fragments } \\
\text { in } 4 \% \text { of cells }\end{array}$ \\
\hline $\begin{array}{l}\text { I.2 } \\
\text { II.1 } \\
\text { II. } 3 \\
\text { II.4 }\end{array}$ & $\begin{array}{l}\mathbf{M} \\
\mathbf{M} \\
\mathbf{F} \\
\mathbf{F}\end{array}$ & $\begin{array}{l}66 \\
33 \\
28 \\
24\end{array}$ & $\begin{array}{c}\mathbf{L} \\
\mathbf{L} \\
\mathbf{L} \\
\mathbf{L} ; \mathbf{F}\end{array}$ & $\begin{array}{r}50 \\
50 \\
40 \\
100\end{array}$ & $\begin{array}{l}46 / X Y \\
46 / X Y \\
46 / X X \\
47 / X X\end{array}$ & Extra small metacen- & $\begin{array}{l}\text { Variant } D \text { and } G \ddagger \\
\text { Variant } D \text { and } G \\
\text { Variant } D \text { and } G \\
\text { Variant } D \text { and } G\end{array}$ \\
\hline II.5 & $\mathbf{F}$ & 24 & L; F & 33 & $47 / X X$ & Extra small metacen- & Variant $D$ and $G$ \\
\hline $\begin{array}{l}\text { II.6 } \\
\text { III. } 2 \\
\text { III. } 3\end{array}$ & $\begin{array}{l}\mathrm{M} \\
\mathrm{F} \\
\mathrm{M}\end{array}$ & $\begin{array}{r}43 \\
4 \\
2\end{array}$ & 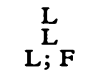 & $\begin{array}{l}40 \\
30 \\
20\end{array}$ & $\begin{array}{l}46 / X Y \\
46 / X X \\
46 / X Y\end{array}$ & & Variant $D$ and $G$ \\
\hline
\end{tabular}

$\star$ See Fig. 1.

† L, lymphocytes from peripheral blood; F, fibroblasts from skin biopsy.

$¥$ Variant $D$ and $G=$ prominent short arms/satellites on one $D$ and one $G$ chromosome in many cells.

cultures only were examined in the case of her other sibs (II.1 and II.3), her husband (II.6), her daughter (III.2), and her parents (I.1 and I.2). The results of the chromosome findings in these cultures are shown in Table I.

The abberrant, supernumerary chromosome was found consistently in the cultures of II.5, her twin sister (II.4), and her mother (I.1), and was morphologically similar in all three of them. It appeared to be slightly smaller and more metacentric than typical $G$ group chromosomes, though the centromere position varied slightly in different cells. The extra chromosome did not show satellites or evidence of satellite association. The mother's (I.1) karyotype revealed, in addition, various inconsistent anomalies of what were considered to be her $\mathrm{X}$ chromosomes. A few cells appeared to be deficient in, or to have an extra, $X$, and, in some, long acentric fragments, approximately the size of an $X$, were present. These findings suggested that the supernumerary chromosome might have originated from a deleted X. Buccal smears revealed no extra Barr bodies and autoradiography of the chromosomes from II.5 with ${ }^{3} \mathrm{H}$ thymidine failed to show significant labelling of the extra metacentric, though one $\mathrm{X}$ was heavily labelled. Partial karyotypes from the family are shown in Fig. 2.

Apart from the abnormalities mentioned, prominent satellites and/or long short arms on a $G$ and a D group chromosome were present in varying numbers of cells from II.5, her twin(II. 4), her brother(II.1), her daughter (III.2), and her father (I.2).

\section{Dermatoglyphs and Blood Groups}

Dermatoglyphic findings on the hands of members of the family are presented in Table II. Carriers of the supernumerary chromosome and non-carrier relatives showed substantially similar features.

Blood group data, given in Table III, show that the fragment segregates independently of $A B O$ and $R h$. The other groups examined give no information.

\section{Discussion}

Identification of small additional chromosomes is important in helping to explain the diverse phenotypes with which they are associated. These chromosomes almost certainly have different origins in different cases, even though they may appear to be morphologically similar. Metacentric fragments, without satellites, could be produced, by deletion, from any chromosome other than those of groups D

TABLE II

DERMATOGLYPHIC FINDINGS ON HANDS OF FAMILY

\begin{tabular}{|c|c|c|c|c|c|c|c|c|c|c|c|c|c|c|c|c|}
\hline \multirow{3}{*}{$\begin{array}{c}\text { Pedigree } \\
\text { No. } \star\end{array}$} & \multirow{3}{*}{ Sex } & \multicolumn{10}{|c|}{ Digital Pattern Types } & \multirow{3}{*}{$\begin{array}{l}\text { Total } \\
\text { Ridge } \\
\text { Count }\end{array}$} & \multirow{3}{*}{$\begin{array}{c}\text { Sum of } \\
\text { Maximal } \\
\text { atd Angles }\end{array}$} & \multirow{3}{*}{$\begin{array}{c}\text { Sum of } \\
a-b \text { Ridge } \\
\text { Counts }\end{array}$} & \multirow{2}{*}{\multicolumn{2}{|c|}{ Palmar Triradii }} \\
\hline & & & & Left & & & & & Right & & & & & & & \\
\hline & & V & IV & III & II & I & I & II & III & IV & $\mathbf{V}$ & & & & Left & Right \\
\hline $\begin{array}{l}\text { I.1 } \\
\text { I.2 } \\
\text { II.I } \\
\text { II. } 3 \\
\text { II.4 } \\
\text { II.5 } \\
\text { II.6 } \\
\text { III. } 2 \\
\text { III. } 3\end{array}$ & $\begin{array}{l}\mathbf{F} \\
\mathbf{M} \\
\mathbf{M} \\
\mathbf{F} \\
\mathbf{F} \\
\mathbf{F} \\
\mathbf{M} \\
\mathbf{F} \\
\mathbf{M}\end{array}$ & $\begin{array}{l}\mathbf{U} \\
\mathbf{W} \\
\mathbf{W} \\
\mathbf{W} \\
\mathbf{U} \\
\mathbf{U} \\
\mathbf{U} \\
\mathbf{R} \\
\mathbf{W}\end{array}$ & $\begin{array}{l}\mathbf{W} \\
\mathbf{W} \\
\mathbf{W} \\
\mathbf{W} \\
\mathbf{W} \\
\mathbf{W} \\
\mathbf{W} \\
\mathbf{U} \\
\mathbf{W}\end{array}$ & $\begin{array}{l}\mathbf{U} \\
\mathbf{U} \\
\mathbf{U} \\
\mathbf{U} \\
\mathbf{U} \\
\mathbf{W} \\
\mathbf{R} \\
\mathbf{W}\end{array}$ & $\begin{array}{l}\mathbf{R} \\
\mathbf{W} \\
\mathbf{W} \\
\mathbf{U} \\
\mathbf{U} \\
\mathbf{W} \\
\mathbf{W} \\
\mathbf{W}\end{array}$ & $\begin{array}{l}\mathbf{W} \\
\mathbf{U} \\
\mathbf{U} \\
\mathbf{U} \\
\mathbf{U} \\
\mathbf{U} \\
\mathbf{U}\end{array}$ & $\begin{array}{l}\mathbf{W} \\
\mathbf{U} \\
\mathbf{W} \\
\mathbf{U} \\
\mathbf{U} \\
\mathbf{U} \\
\mathbf{U} \\
\mathbf{U}\end{array}$ & $\begin{array}{l}\mathbf{U} \\
\mathbf{W} \\
\mathbf{U} \\
\mathbf{U} \\
\mathbf{U} \\
\mathbf{W} \\
\mathbf{W} \\
\mathbf{W}\end{array}$ & $\begin{array}{l}\mathbf{U} \\
\mathbf{W} \\
\mathbf{W} \\
\mathbf{U} \\
\mathbf{U} \\
\mathbf{U} \\
\mathbf{W}\end{array}$ & $\begin{array}{l}\mathbf{W} \\
\mathbf{W} \\
\mathbf{W} \\
\mathbf{W} \\
\mathbf{W} \\
\mathbb{W} \\
\mathbf{W} \\
\mathbb{W}\end{array}$ & $\begin{array}{l}\mathbf{U} \\
\mathbf{W} \\
\mathbf{W} \\
\mathbf{W} \\
\mathbf{U} \\
\mathbf{U} \\
\mathbf{U} \\
\mathbf{W}\end{array}$ & $\begin{array}{l}159 \\
239 \\
208 \\
167 \\
153 \\
172 \\
162 \\
130 \\
181\end{array}$ & $\begin{array}{l}83 \\
81 \frac{1}{2} \\
81 \\
94 \\
90 \frac{1}{2} \\
78 \\
83 \frac{1}{2} \\
100 \\
92 \frac{1}{2}\end{array}$ & $\begin{array}{l}81 \\
84 \\
77 \\
82 \\
83 \\
83 \\
90 \\
75 \\
71\end{array}$ & $\begin{array}{l}a b c d t^{\prime} t^{b} \\
a b c d t t^{b} \\
a b c d t t^{b} \\
a b c d t^{\prime} t^{b} \\
a b c^{\prime} d t^{\prime} t^{b} e e^{\prime} \\
a b c d t t^{b} \\
a b c d t t^{b} \\
a b c d t^{\prime} t^{b} \\
a b c d t t^{\prime} t^{b}\end{array}$ & $\begin{array}{l}a b c d t \\
a b c d t t^{b} \\
a b c d t t^{b} \\
a b c d t t^{b} \\
a b c d t^{\prime} t^{b} \\
a b c d t t^{b} \\
a b c d t^{b} \\
a b c d t^{\prime} t^{b} \\
a b c d t t^{\prime}\end{array}$ \\
\hline
\end{tabular}

$\star$ See Fig. 1. 


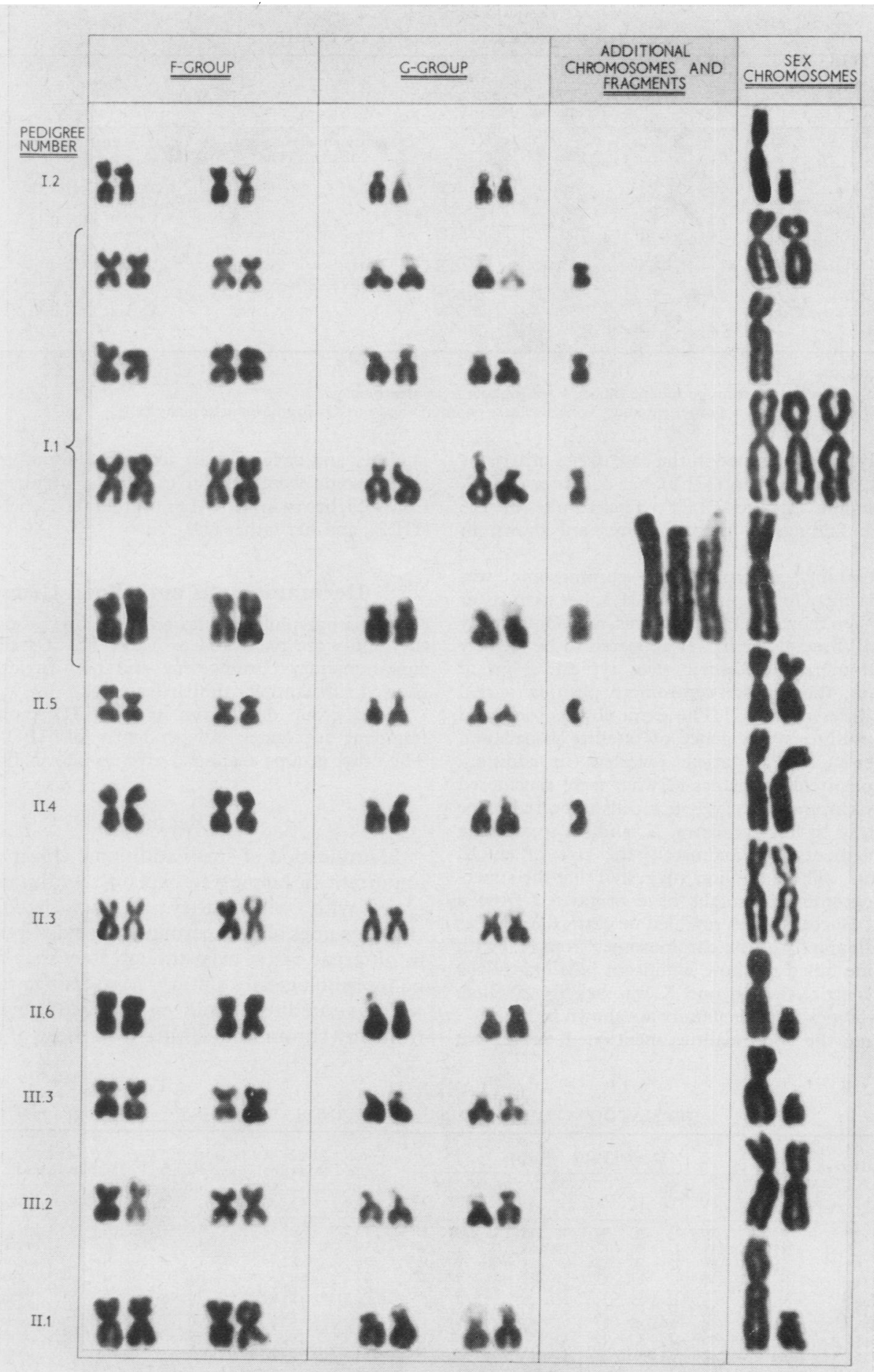

FIG. 2. Partial karyotypes of the family. 
TABLE III

BLOOD GROUPS OF FAMILY

\begin{tabular}{|c|c|c|c|c|c|c|c|c|c|c|c|}
\hline $\begin{array}{c}\text { Pedigree } \\
\text { No. }\end{array}$ & ABO & MNS & $\mathbf{P}_{1}$ & Rh & $\mathbf{L u}^{\mathbf{a}}$ & $\mathbf{K}$ & $\operatorname{Le}^{a}$ Le $^{b}$ & Fy ${ }^{a} F y^{b}$ & $\mathbf{X g}^{\mathrm{a}}$ & $\mathrm{Jk}^{\mathbf{a}} \mathbf{J k} \mathbf{k}^{\mathrm{b}}$ & $\begin{array}{c}\text { Extra } \\
\text { Chromo- } \\
\text { some }\end{array}$ \\
\hline $\begin{array}{l}\text { I.1 } \\
\text { I.2 } \\
\text { II.1 } \\
\text { II. } 3 \\
\text { II.4 } \\
\text { II.5 } \\
\text { II. } 6 \\
\text { III. } 2 \\
\text { III. } 3\end{array}$ & $\begin{array}{l}\mathbf{B} \\
\mathbf{A}_{1} \\
\mathbf{A}_{1} \mathbf{B} \\
\mathbf{A}_{2} \mathbf{B} \\
\mathbf{A}_{1} \\
\mathbf{A}_{1} \\
O \\
O \\
\mathbf{A}_{1}\end{array}$ & $\begin{array}{l}\text { MSMS } \\
\text { MSNs } \\
\text { MSMS } \\
\text { MSNs } \\
\text { MSMS } \\
\text { MSMS } \\
\text { MSMs } \\
\text { MSMS } \\
\text { MSMs }\end{array}$ & $\begin{array}{l}+ \\
+ \\
+ \\
+ \\
+ \\
+ \\
+ \\
+ \\
+\end{array}$ & $\begin{array}{l}R_{1} r \\
R_{2} r \\
R_{2} r \\
r r \\
r r \\
r r \\
r r \\
R_{1} R_{2} \\
R_{2} r \\
R_{1} r\end{array}$ & $\begin{array}{l}- \\
\overline{-} \\
\overline{-} \\
\overline{-} \\
\overline{-} \\
-\end{array}$ & $\begin{array}{l}- \\
- \\
- \\
- \\
- \\
- \\
-\end{array}$ & 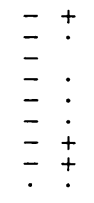 & 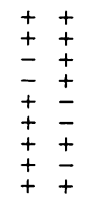 & $\begin{array}{l}+ \\
+ \\
+ \\
+ \\
+ \\
+ \\
+\end{array}$ & 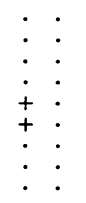 & $\begin{array}{l}+ \\
- \\
\overline{-} \\
+ \\
+ \\
- \\
-\end{array}$ \\
\hline
\end{tabular}

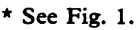

and $\mathrm{G}$, though these two groups could also be implicated if the satellites are lost. If an autosome is involved, a variety of pathological effects might be expected, depending partly on the chromosome from which the fragment was derived. When there are features of the 17-18 trisomy syndrome, extra fragments have been thought, in some instances, to have originated by deletion of the long arms of a 17 or 18 chromosome or by formation of a 17 or 18 short arm isochromosome (Frøland et al., 1963; Gustavson et al., 1964; Taft et al., 1965; Tamburro and Johnson, 1966; Ferrante et al., 1968; Ishmael and Laurence, 1968).

Some supernumerary fragments may be inert and their association with abnormal phenotypes coincidental. This proposition is strengthened by the occurrence of such fragments in apparently normal people. In such circumstances, it is possible that an inactivated $\mathrm{X}$ chromosome is implicated. This may be the case in the present family where, in addition to the fragment, $\mathrm{X}$ chromosome anomalies were observed in I.1. However, the association of sex chromosome anomalies in I.1 and the presence of the fragment may be coincidental. Large acentric fragments have been occasionally seen in cultures from elderly patients (Anders et al., 1968), and sex chromosome aneuploidy has been reported to increase with age (Jacobs et al., 1963; Jacobs, Court Brown, and Doll, 1961).

Specific procedures, useful in investigating intact $\mathrm{X}$ chromosomes, did not help in the identification of the supernumerary fragment in the present family. It is not surprising, in view of its small size, that buccal smears failed to reveal extra Barr bodies, or that autoradiography did not result in diagnostically useful labelling of the fragment. Nor were $\mathrm{Xg}$ blood group findings helpful in identifying the extra chromosome. However, there is evidence that $\mathrm{Xg}$, carried on an abnormal $\mathrm{X}$, is inactivated (Race and Sanger, 1968, 1969). Thus in the family reported here, there is no firm evidence as to the identity of the supernumerary fragment, though derivation from a deleted $\mathrm{X}$ chromosome is a possibility.

\section{Summary}

The presence of a small supernumerary, metacentric chromosome in three phenotypically normal members of a family is recorded. The possible origins of such chromosomes and the effects of their presence are briefly discussed.

We are grateful to Professor L. S. Penrose for helpful comments, to Dr. Ruth Sanger for supplying and commenting on the data in Table III, to Dr. Renate Lax for autoradiographic analysis, and to Mr. A. J. Lee for drawing Fig. 1.

This study was supported, in part, by the Institute for Research into Mental Retardation through a grant from the Wates Foundation.

\section{REFERENCES}

Anders, J. M., Jagiello, G., Polani, P. E., Gianelli, F., Hamerton, J. L., and Leiberman, D. M. (1968). Chromosome findings in chronic psychotic patients. British fournal of Psychiatry, 114, 1167-1174.

Dekaban, A. (1965). Twins, probably monozygotic: one mongoloid with 48 chromosomes, the other normal. Cytogenetics, 4, 227-239.

Ferrante, E., Bruni, L., Laurenti, F., and Dezza, G. C. (1968). Parziale trisomia autosomica in soggetto affetto da ritardo mentale e lievi note dismorfiche. Minerva Pediatrica, 20, 522-529.

Fischer, M., and Haslund, J. (1968). Severe mental retardation in Turner's syndrome and an additional mosaic with a centric chromosome fragment. Acta Genetica et Statistica Medica, 18, 487-495.

Frøland, A., Holst, G., and Terslev, E. (1963). Multiple anomalies associated with an extra small autosome. Cytogenetics, 2, 99-106.

Ginsberg, J., Dignan, P., and Soukup, S. (1968). Ocular abnormality associated with extra small autosome. American fournal of Ophthalmology, 65, 740-746.

Gustavson, K.-H., Atkins, L., and Patricks, I. (1964). Diverse chromosomal anomalies in two siblings. Acta Paediatrica, 53, 371-376.

Hultén, M., Lindsten, J., Fraccaro, M., Mannini, A., and Tiepolo, L. (1966). Extra minute chromosome in somatic and germ-line cells of the same person. Lancet, 2, 22-24.

Ishmael, J., and Laurence, K. M. (1968). An extra small metacentric chromosome in a mentally retarded boy. Fournal of Medical Genetics, 5, 335-340.

Jacobs, P. A., Brunton, M., Court Brown, W. M., Doll, R. and Goldstein, H. (1963). Changes of human chromosome count distributions with age: evidence for a sex difference. Nature (London), 197, 1080-1081.

-, Court Brown, W. M., and Doll, R. (1961). Distribution of human chromosome counts in relation to age. Nature (London), 191, 1178-1180. 
Mukherjee, A. B., Partington, M. W., Simpson, N. E., and Walmsley, K. A. (1968). Multiple anomalies associated with a small extra metacentric autosome. Fournal of Medical Genetics, 5, 329-334.

Race, R. R., and Sanger, R. (1968). Blood Groups in Man, 5th ed., p. 577. Blackwell, Oxford.

, and - (1969). $\mathrm{Xg}$ and sex-chromosome abnormalities. British Medical Bulletin, 25, 99-103.

Smith, K. D., Steinberger, E., Steinberger, A., and Perloff, W. H. (1965). A familial centric chromosome fragment. Cytogenetics, 4, 219-226.
Taft, P. D., Dodge, P. R., and Atkins, L. (1965). Mental retardation and multiple congenital anomalies. Association with extra small metacentric chromosome. American fournal of Diseases of Children, 109, 554-557.

Tamburro, R. F., and Johnson, C. E. (1966). An extra small metacentric chromosome in a female child. Fournal of Medical Genetics, 3, 295-297.

Townes, P. L. (1968). Latent aneuploidy in father and grandfather of doubly aneuploid child: Mongolism in a child with 48 chromosomes. Fournal of Pediatrics, 73, 97-100. 